\title{
STUDI KOMPARATIF TENTANG KEMAMPUAN KONEKSI MATEMATIS SISWA YANG BELAJAR DENGAN PENDEKATAN TEMATIK INTEGRATIF MELALUI MODEL WEBBED DAN SISWA YANG BELAJAR MELALUI DIRECT INSTRUCTION
}

\author{
Ayu Amelia \\ SDN 069 Cipamokolan Derwati \\ ayuamelia0287@gmail.com
}

\begin{abstract}
ABSTRAK
Tujuan dari pembelajaran matematika adalah agar siswa dapat memiliki kemampuan koneksi matematis yang baik. Penelitian ini bertujuan untuk mengkaji, membandingkan, dan mendeskripsikan kemampuan koneksi dan peningkatan kemampuan koneksi matematis siswa yang belajar dengan pendekatan tematik integratif melalui model webbed dan direct instruction ditinjau dari level kemampuan siswa tinggi dan rendah. Penelitian ini menggunakan metode kuasi eksperimen dengan desain penelitian yaitu pretes-postes dua perlakuan (the pretest-post-test two treatment design). Metode yang digunakan dalam penelitian ini adalah metode kuasi eksperimen dengan instrumen test kemampuan komunikasi matematis siswa dan angket sikap siswa. Analisis data untuk menguji hipotesis adalah $\mathrm{N}$-gain ternormalisasi dan Uji statistik non parametrik Mann Whitney, dan angket sikap siswa dengan rata-rata skor subjek. Populasi dalam penelitian ini adalah siswa sekolah dasar kelas IV SDN 069 Cipamokolan Derwati Kota Bandung, Populasi langsung diajdikan sampel. Instrumen yang digunakan berupa tes tipe uraian yang dapat mengukur kemampuan koneksi matematis siswa. Berdasarkan analisis data hasil penelitian, diperoleh kesimpulan bahwa (1) kemampuan koneksi matematis antara siswa yang belajar dengan pendekatan tematik integratif melalui model webbed lebih baik daripada siswa yang belajar dengan direct instruction, (2) terdapat perbedaan peningkatan kemampuan koneksi matematis siswa yang belajar dengan pendekatan tematik integratif melalui model webbed dan siswa yang belajar dengan direct instruction ditinjau dari level kemampuan siswa tinggi dan rendah, (3) kemampuan koneksi matematis siswa kelompok tinggi yang belajar dengan pendekatan tematik integratif melalui model webbed lebih baik daripada siswa kelompok tinggi yang belajar melalui direct instruction, (4) kemampuan koneksi matematis siswa kelompok rendah yang belajar dengan pendekatan tematik integratif melalui model webbed lebih baik daripada siswa kelompok rendah yang belajar melalui direct instruction.
\end{abstract}

Kata Kunci : Kemampuan koneksi matematis, pendekatan tematik integratif melalui model webbed, Direct Instruction.

\begin{abstract}
The purpose of learning mathematics is to have good mathematical connection skills. This study aims to examine, compare, and describe the connection ability and increase the mathematical connection ability of students who study with an integrative thematic approach through a webbed model and direct instruction in terms of high and low student ability levels. This study uses a quasiexperimental method with a research design, the pretest-post-test two treatment design. The method used in this study is a quasi-experimental method with a test instrument for students' mathematical communication skills and student attitude questionnaires. Data analysis to test the hypothesis is the
\end{abstract}


normalized N-gain and Mann-Whitney non-parametric statistical test and student attitude questionnaire with the average score of the subject. The population in this study were fourth-grade elementary school students at SDN 069 Cipamokolan Derwati, Bandung City. The instrument used is a descriptive type test that can measure students' mathematical connection abilities. Based on the research data analysis, the result of this study is (1) the mathematical connection ability between students who studied with an integrative thematic approach through the webbed model was better than students who studied with direct instruction. (2) there were differences in improving students' mathematical connection abilities who studied with this approach. Students who learn with Integrative thematic through the web model compared to direct instruction in terms of high and low student ability levels. (3) the mathematical connection ability of high group students who study with an integrative thematic approach through the webbed model is better than high group students who learn through direct instruction. (4) the mathematical connection ability of students in the low group who studied with an integrative thematic approach through the webbed model was better than the students in the low group who learned through direct instruction.

Keywords: Mathematical connection ability, integrative thematic approach through webbed model, Direct Instruction.

\section{PENDAHULUAN}

Koneksi matematis berasal dari bahasa Inggris yakni mathematical connection. Istilah ini dipopulerkan oleh NCTM dan dijadikan sebagai salah satu standar kurikulum. Koneksi matematis bertujuan untuk membantu siswa dalam memperluas wawasannya, untuk memandang matematika sebagai suatu keastuan (integrasi) dari keseluruahan materi pembelajaran dan bukan merupakan suatu bagian dari suatu topik tertentu dan dapat menggunakan seluruh konsep yang ada dalam matematika baik di sekolah maupun di luar sekolah. Hal ini sejalan dengan apa yang dikemukakan oleh NCTM (1989, hlm. 84) yang menyebutkan bahwa tujuan koneksi matematis di sekolah dasar adalah “... to help sudent broaden their perspective, to view mathematics as an integrated whole rather than as an isolated set of topics, and to knowledge its relevance and usefullness both in and out of scholl".

Dari penjelasan di atas, dapat diketahui bahwa kemampuan koneksi matematis merupakan suatu kemampuan yang perlu dimiliki oleh siswa. Menurut Sumarno (2003), ada beberapa indikator dari kemampuan koneksi matematis yang dapat dikembangkan yakni : (1) Mencari hubungan berbagai representasi konsep dan prosedur; (2) Memahami hubungan antar topik matematika, (3) Menggunakan matematika dalam bidang studi lain atau kehidupan sehari-hari, (4) Memahami representasi ekuivalen konsep atau prosedur yang sama, dan (5) Mencari koneksi antar topik matematika dan antara topik matematika dengan topik lain. 
Kusumah (2008, hlm. 19) mengungkapkan bahwa koneksi matematis dapat diartikan sebagai keterkaiatan antara konsep-konsep matematika secara internal yaitu berhubungan dengan matematika itu sendiri ataupun keterkaitan secara eksternal, yaitu matematika dengan bidang lain, baik bidang studi yang lain maupun dengan kehidupan sehari-hari. Sehubungan dengan hal tersebut maka dalam pembelajaran matematika diperlukan adanya penekanan terhadap koneksi, baik dengan matematika itu sendiri, dengan mata pelajaran lain, maupu dengan kehidupan sehari-hari.

NCTM (dalam Yaniawati, 2001, hlm. 14) membagi koneksi matematis menjadi tiga macam, yaitu: (1) koneksi antar topik matematika, (2) koneksi dengan disiplin ilmu yang lain, dan (3) koneksi dengan kehidupan sehari-hari. Pendapat yang hampir serupa juga dikemukakan oleh Kutz (1991) yang berpendapat bahwa koneksi matematis berkaitan dengan koneksi internal dan koneksi eksternal. Koneksi internal meliputi koneksi antar topik matematika sedangkan koneksi eksternal meliputi koneksi dengan mata pelajaran lain dan koneksi dengan kehidupan sehari-hari. Kemudian Riedesel (Kutz, 1991, hlm. 15) membagi koneksi matematis menjadi lima macam, yaitu: a) koneksi antar topik dalam matematika; b) koneksi antar beberapa macam ilmu pengetahuan; c) koneksi antara beberapa macam representasi; d) koneksi dari matematika ke daerah kurikulum lain; dan e) koneksi siswa dengan matematika.

Bruner (dalam Ruseffendi, 1991, hlm. 152) mengemukakan bahwa dalam matematika setiap konsep itu berkaitan dengan konsep yang lain. Begitu pula antara yang lainnya, misalnya antara dalil dan dalil, antara teori dan teori, antara topik dengan topik, antara cabang matematika (aljabar dengan geometri misaknya). Oleh karena itu, agar siswa lebih berhasil dalam belajar matematika maka siswa harus lebih banyak diberi kesempatan untuk melihat kaitan-kaitan itu.

Dari beberapa pendapat di atas, dapat diketahui bahwa koneksi matematis tidak hanya mencakup masalah yang berhubungan dengan matematika saja, namun berkaitan juga dengan mata pelajaran yang lain serta dengan kehidupan sehari-hari. Kemampuan koneksi matematis adalah kemampuan siswa dalam mengaitkan antar suatu topik, baik topik dalam matematika itu sendiri, dengan bidang lain maupun dengan kehidupan sehari-hari.

Koneksi matematis yang dimaksud dalam penelitian ini meliputi koneksi internal (koneksi antar topik matematika) dan koneksi eksternal (koneksi topik matematika dengan topik diluar matematika) sesuai dengan pendapat Kutz. Sedangkan kemampuan koneksi matematis yang dimaksud adalah kemampuan siswa dalam mengaitkan topik mateatika yang 
sedang dibahas dengan topik matematika lainnya, dengan mata pelajaran lain atau dengan kehidupan sehari-hari. Kemampuan tersebut secara umum dilihat dari kemampuan siswa dalam menyelesaikan soal-soal koneksi, baik soal koneksi internal maupun soal koneksi ekternal.

Baroody mengungkapkan dua alasan pentingnya komunikasi dalam matematika, alasan yang pertama karena matematika merupakan alat untuk mengkomunikasikan berbagai ide dengan jelas, tepat dan ringkas, sedangkan alasan yang kedua yaitu sebagai aktivitas sosial dalam pembelajaran matematika di sekolah, dimana adanya interaksi guru dan siswa, maupun siswa dengan siswa (Widiatmika, 2019).

Pressini dan Bassett berpendapat, “ Bahwa tanpa komunikasi dalam matematika, kita akan memiliki sedikit keterangan, data dan fakta tentang pemahaman siswa dalam melakukan proses aplikasi matematika" (Yaniawati, 2010). Sedangkan menurut Damar (2017) seorang siswa mampu bernalar dan memecahkan masalah dengan baik sebagai suatu kegiatan atau aktivitas berpikir, dismping itu juga ia harus mampu mengkomunikasikan kemampuan tersebut secara nyata dalam bentuk lisan dan tulisan. Kesulitan belajar siswa terjadi karena kurangnya pengetahuan dan keterampilan siswa dalam menyelesaikan soalsoal tes kemampuan komunikasi matematik (Apianti, 2017).

Indikator kemapuan komunikasi matematis menurut Sumarmo (dalam Fauziah, 2018) antara lain:

1. Melukiskan atau mempersentasikan benda nyata, gambar dan diagram dalam bentuk ide, situasi dan relasi.

2. Menjelaskan ide, situasi dan relasi matematika secara tulisan dengan menggunakan benda nyata, gambar, grafik dan ekspresi aljabar.

3. Menyatakan sehari-hari dalam bahasa atau simbolik matematika atau menyusun model matematika suatu peristiwa.

Berdasarkan fakta dilapangan hanya 30\% dari total keseluruhan siswa SMK Kesehatan yang mencapai nilai KKM pada Ujian Akhir Semester ganjil di kelas X tahun ajaran 2019/2020. Hal ini menunjukan kualitas kemampuan komunikasi matematis siswa saat ini masih rendah. Pembelajaran matematika belum mampu membuat siswa untuk menyalurkan ide-ide matematiknya (Lisna, 2014). Oleh karena itu komunikasi sangat penting (Soleh, 2020). Komunikasi matematis menurut Baroody (dalam Widiatmika, 2019) adalah alat untuk mengkomunikasikan berbagai ide dengan jelas, tepat, dan ringkas. 
Guru mengungkapkan siswa banyak mengalami kesulitan pada pelajaran matematika dalam materi trigonometri. Untuk indikator kemampuan komunikasi matematis yang diindikasikan menggunakan gambar, diagram, grafik, atau rumus skor rata-rata yang diperoleh siswa rentang skala 0-4. Sehingga perlu penerapan pembelajaran yang tepat untuk melatih dan mengembangkan komunikasi matematis. Selanjutnya skor akhir yang diperoleh ditransformasikan menjadi nilai dengan skala (0-100) (Mawaddah, 2015).

Pendekatan tematik integratif yang yaang kini dikembangkan dalam kurikulum 2013 merupakan salah satu perwujudan dari pembelajaran terpadu. Kurniawan (2011) menjelaskan bahwa inti dari pembelajaan terpadu adalah memfokuskan isi bahan belajar dari sejumlah mata pelajaran dalam satu fokus, batas-batas materi dan nama mata pelajaran sudah tidak tampak lagi.

Menilik perkemangan konsep pendekatan terpadu di Indonesia, pada saat ini model pembelajaran terpadu yang dipelajari dan berkembang adalah model pembelajaran terpadu yang dikemukakan oleh Fogarty. Fogarty (dalam Kurniawan, 2011, hlm. 54) menyatakan bahwa Webbed model, model terjala atau jejaring tema (webbed) ini merupakan model yang paling populer. Dalam model ini ibarat kita memandang pembelajaran menggunakan teleskop untuk memperoleh gambaran menyeluruh mengemai subjek dan aktivitasnya.

Organisasi pembelajaran model terjala (webbed) adalah pendekatan tematik dalam pengintegrasian mata pelajaran. Satu tema dijadikan rujukan untuk membahas materi sejumlah mata pelajaran yang sejalan atau memiliki keterkaitan ide dan tema. Tema menjadi sesuatu yang sangat penting untuk merajut topik materi dari sejumlah mata pelajaran sehingga menjadi sebuah uraian yang terpadu.

Direct Instruction atau pembelajaran langsung digunakan oleh para peneliti untuk merujuk pola-pola pembelajaran dimana guru lebih banyak menjelaskan konsep atau keterampilan kepada sejumlah kelompok siswa dan menguji keterampilan siswa melalui latihan-latihan di bawah bimbingan dan arahan guru. Dengan demikian tujuan pembelajaran pada Direct Instruction distrukturkan oleh guru.

Flanders (Suryadi, 2005) menyatakan bahwa pembelajaran Direct Instruction lebih berpusat pada guru $(>50 \%)$. Model pembelajaran Direct Instruction dirancang untuk menciptakan lingkungan belajar terstruktur, dan berorientasi akademik. Guru berperan sebagai penyampai informasi, dalam melakukan tugasnya, guru dapat menggunakan berbagai media misalnya flim, tape recorder, gambar, peragaan, dsb. 


\section{METODE PENELITIAN}

Metode penelitian yang digunakan pada penelitian ini yaitu metode kuasi eksperimen. Menurut Sudjana (2004, hlm. 19) metode penelitian eksperimen dapat diartikan sebagai sutau metode yang mengungkap hubungan antara dua variabel atau lebih atau mencari pengaruh suatu variabel terhadap variabel lainnya. Penelitian ini menggunakan desain penelitian eksperimen kuasi. Sampel diambil dari dua kelas. Kelas pertama merupakan kelompok eksperimen yang diberikan pembelajaran dengan metode pembelajaran Problem Based Learning (PBL) sedangkan, kelas kedu merupakan kelompok kontrol yang diberikan metode pembelajaran konvensional. Kedua kelompok tersebut diberikan pretest dan posttest yaitu tes kemampuan komunikasi matematis. Karena penelitian ini menggunakan eksperimen kuasi maka tidak menggunakan kelas acak namun menerima subjek apa adanya.

Berikut design penelitian yang digunakan:

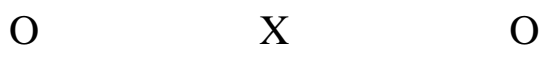

$\mathrm{O} \quad \mathrm{O}$

Keterangan:

$\mathrm{X}$ : Pembelajaran Problem Based Learning (PBL)

$\mathrm{O}:$ Pretest/posttest

Populasi pada penelitian ini adalah seluruh siswa kelas IV SDN 069 Cipamokolan Derwati, kemudian populasi tersebut langsung dijadikan sebagai sampel penelitian. Teknik penelitian ini ada dua kelompok subjek penelitian yaitu kelompok pertama mendapat perlakuan pembelajaran dengan pendekatan tematik integratif melalui model webbed, dan kelompok kedua mendapat perlakuan pembelajaran dengan pembelajaran melalui direct instruction. Kedua kelompok diberikan pretes dan postes dengan menggunakan instrumen tes yang sama. Jenis desain penelitian yang digunakan dalam penelitian ini adalah desain pretes-postes dua perlakuan (The pretest-posttest two treatment design). Pada desain ini subjek tidak dikelompokkan secara acak.

\section{HASIL DAN PEMBAHASAN}

Berdasarkan hasil tes Kemampuan awal Matematika (KAM), pretes, postes dan NGain diperoleh data sebagai berikut :

\section{Pengolahan Data Tes Kemampuan Awal Matematis (KAM) Siswa.}


Kelas eksperimen 1 terdiri dari 25 orang siswa (5 orang level tinggi, 15 orang level sedang, dan 5 orang level rendah). Sedangkan kelas eksperimen 2 terdiri dari 25 orang siswa 4 orang level tinggi, 15 orang level sedang, dan 6 orang level rendah).

\section{Kemampuan Koneksi Matematis sebelum Pembelajaran}

Dari perolehan nilai rata-rata hasil pretest secara umum dapat dikatakan bahwa bahwa rata-rata nilai dari hasil pretes pada kedua kelas tersebut memang tidak jauh berbeda. Hal ini dapat terlihat dari perolehan nilai rata-rata hasil pretest untuk kelas yang belajar dengan pendekatan tematik integratif melalui model webbed adalah 18,24 sedangkan untuk kelas yang belajar dengan model pembelajaran direct instruction nilai rata-rata hasil pretesnya adalah 18,04 .

Dari hasil perhitungan ternyata didapat bahwa nilai probabilitas pada taraf signifikansi (2-tailed) adalah 0,849. Oleh karena nilai probabilitas adalah 0,849>0,05, maka maka $\mathrm{H}_{0}$ diterima atau kemampuan awal koneksi matematis siswa sebelum dlaksanakan pembelajaran pada kedua kelas tersebut tidak berbeda.

\section{Kemampuan Koneksi Matematis Setelah Pembelajaran}

Secara umum terdapat perbedaan kemampuan koneksi matematis siswa pada kedua kelas tersebut. Perbedaan tersebut dapat dilihat dari perolehan nilai hsail tes akhir (posttest) Kemampuan Koneksi Matematis siswa pada kedua kelas tersebut. Hal ini dapat terlihat dari perolehan nilai rata-rata hasil posttest untuk kelas yang belajar dengan pendekatan tematik integratif melalui model webbed adalah 26,52 sedangkan untuk kelas yang belajar dengan model pembelajaran direct instruction nilai rata-rata hasil Posttestnya adalah 20,40.

Berdasarkan hasil perhitungan, diketahui bahwa $t_{\text {hitung }}$ adalah 5,458. Sedangkan pada taraf signifikansi $5 \%(0,05), \mathrm{t}_{1-\alpha}$ yaitu $\mathrm{t}_{\text {kritis }}=1,677$. Dengan melihat hasil $\mathrm{t}_{\text {hitung }}$ dan $\mathrm{t}_{1-\alpha}$ maka trerliht bahwa $t_{\text {hitung }}=5,458>\mathrm{t}_{\text {kritis }}=1,677$. Dengan demikian $\mathrm{H}_{0}$ ditolak dan $\mathrm{H}_{1}$ diterima atau kemampuan koneksi matematis siswa yang memperoleh pembelajaran matematika dengan pendekatan tematik integratif melalui model webbed lebih baik dari pada siswa yang memperoleh pembelajaran dengan model pembelajaran direct instruction.

\section{Peningkatan Kemampuan Koneksi Matematis Siswa}

Adapun hasil perolehan N-gain di kelas yang belajar dengan pendekatan tematik integratif melalui model webbed adalah 0,39 yang artinya peningkatannya tergolong sedang. Berbeda dengan kelas yang belajar dengan pendekatan tematik integratif melalui model webbed, di kelas yang belajar melalui direct instruction hasil perolehan N-gainnya adalah 0,11 artinya peningkatannya tergolong rendah. 
Oleh karena data N-Gain pada kelas yang belajar dengan pendekatan tematik integratif model webbed tidak berdistribui normal sedangkan data $\mathrm{N}$-gain pada kelas yang belajar melalui direct instruction berdistribusi normal dan varian kedua kelas tersebut tidak homogen, maka uji perbedaan yang dapat dilakukan adalah menggunakan uji statistik non parametrik melalui uji Mann- Whitney.

Uji hipotesis 1 Berdasarkan perhitungan, maka $Z_{\text {hitung }}$ adalah 6,067. Sedangkan pada taraf signifikansi $5 \%(0,05), \mathrm{Z}_{\text {kritis }}=1,64$. Maka $\mathrm{Z}_{\text {hitung }}=6,067>\mathrm{Z}_{\text {kritis }}=1,64$. Dengan demikian $\mathrm{H}_{0}$ ditolak dan $\mathrm{H}_{1}$ diterima. Artinya, Peningkatan kemampuan koneksi matematis siswa yang memperoleh pembelajaran matematika dengan pendekatan tematik integratif melalui model webbed lebih baik daripada siswa yang memperoleh pembelajaran dengan model pembelajaran direct instruction.

Uji Hipotesis 2 Peningkatan Kemampuan Koneksi Matematis Siswa ditinjau dari Level Kemampuan Siswa Tinggi dan Rendah

Pada kelas yang menggunakan pendekatan tematik integratif melalui model webeed rata-rata N-Gain siswa kelompok tinggi adalah 0,59, dan siswa kelompok rendah adalah 0,34 . Adapun pada kelas yang menggunakan model direct instruction perolehan rata-rata $\mathrm{N}$ Gain siswa kelompok tinggi adalah 0,16, dan siswa kelompok rendah adalah 0,09.

Dari uji anova dua jalur di atas di atas, diperoleh tingkat signifikansi untuk peningakatan kemampuan koneksi matematis siswa berdasarkan level kemampuan siswa tinggi dan rendah sebesar 0,000. Artinya $0,000<0,05$ maka $\mathrm{H}_{0}$ ditolak dan $\mathrm{H}_{1}$ diterima yang berarti terdapat perbedaan peningkatan kemampuan koneksi matematis siswa yang belajar dengan pendekatan tematik integratif melalui model webbed dan siswa yang belajar melalui direct instruction ditinjau dari level kemampuan siswa tinggi dan rendah.

Selanjutnya untuk menguji hipotesis penelitian 3 Berdasarkan uji anova dua jalur pada tabel 4.15, diperoleh tingkat signifikansi untuk interaksi level kemampuan siswa dan model pembelajaran sebesar 0,001 . Artinya $0,001<0,05$ maka $\mathrm{H}_{0}$ ditolak dan $\mathrm{H}_{1}$ diterima yang berarti terdapat pengaruh interaksi level kemampuan siswa dan model pembelajaran terhadap peningkatan kemampuan koneksi matematis siswa.

Uji Hipotesis 4 perbedaan kemampuan koneksi matematis siswa kelompok tinggi yang belajar dengan pendekatan tematik integratif melalui model webbed dan siswa kelompok tinggi yang belajar melalui direct instruction. Berdasarkan data hasil penelitian diketahui bahwa pada kelas yang menggunakan pendekatan tematik integratif melalui model webbed rata-rata $\mathrm{N}$-Gain siswa kelompok tinggi adalah 0,59 sedangkan pada kelas yang 
belajar melalui direct instruction perolehan rata-rata N-Gain siswa kelompok tinggi adalah 0,16 . Dari perolehan rata-rata $\mathrm{N}-$ Gain tersebut secara umum terlihat bahwa rata-rata N-Gain siswa kelompok tinggi pada kelas yang menggunakan pendekatan tematik integratif melalui model webbed lebih baik daripada rata-rata $\mathrm{N}$-Gain siswa kelompok tinggi pada kelas yang belajar melalui direct instruction .

Berdasarkan perhitungan di atas, maka thitung adalah 9,478. Sedangkan pada taraf signifikansi $5 \%(0,05), \mathrm{t}_{1-\alpha}$ yaitu $\mathrm{t}_{\text {kritis }}=1,895$. Dengan melihat hasil $\mathrm{t}_{\text {hitung }}$ dan $\mathrm{t}_{1-\alpha}$ maka trerliht bahwa $t_{\text {hitung }}=9,478>\mathrm{t}_{\text {kritis }}=1,895$. Dengan demikian $\mathrm{H}_{0}$ ditolak dan $\mathrm{H}_{1}$ diterima . Artinya , Kemampuan koneksi matematis siswa kelompok tinggi yang belajar dengan pendekatan tematik integratif melalui model webbed lebih baik daripada siswa kelompok tinggi yang belajar melalui direct instruction.

Uji Hipotesis 5 perbedaan kemampuan koneksi matematis siswa kelompok tinggi yang belajar dengan pendekatan tematik integratif melalui model webbed dan siswa kelompok tinggi yang belajar melalui direct instruction. Berdasarkan data hasil penelitian, telah diketahui bahwa pada kelas yang menggunakan pendekatan tematik integratif melalui model webeed rata-rata $\mathrm{N}$-Gain siswa kelompok rendah adalah 0,34 sedangkan pada kelas yang belajar melalui direct instruction perolehan rata-rata N-Gain siswa kelompok rendah adalah 0,09. Dari perolehan rata-rata N-Gain tersebut secara umum terlihat bahwa rata-rata $\mathrm{N}$-Gain siswa kelompok rendah pada kelas yang menggunakan pendekatan tematik integratif melalui model webeed lebih baik daripada rata-rata $\mathrm{N}$-Gain siswa kelompok tinggi pada kelas yang belajar melalui direct instruction .

Berdasarkan hasil perhitungan, maka $t_{\text {hitung }}$ adalah 14,274 . Sedangkan pada taraf signifikansi $5 \%(0,05), \mathrm{t}_{1-\alpha}$ yaitu $\mathrm{t}_{\text {kritis }}=1,833$. Dengan melihat hasil $\mathrm{t}_{\text {hitung }}$ dan $\mathrm{t}_{1-\alpha}$ maka trerliht bahwa $t_{\text {hitung }}=14,274>t_{\text {kritis }}=1,833$. Dengan demikian $\mathrm{H}_{0}$ ditolak dan $\mathrm{H}_{1}$ diterima. Artinya , Kemampuan koneksi matematis siswa kelompok rendah yang belajar dengan pendekatan tematik integratif melalui model webbed lebih baik daripada siswa kelompok rendah yang belajar melalui direct instruction.

Berdasarkan pada analisis data yang telah dipaparkan pada hasil penelitian sebelumnya terungkap bahwa baik pembelajaran dengan pendekatan tematik integratif melalui model webbed maupun pembelajaran dengan direct instruction dapat meningkatkan kemampuan koneksi matematis siswa. Hal ini terlihat pada analisis N-Gain yang menunjukkan adanya peningkatan dari nilai pretes ke postes setelah diberikannya treatman pada kedua kelas penelitian. Namun berdasarkan hasil uji statistik diketahui bahwa 
kemampuan koneksi matematis siswa yang belajar dengan pendekatan tematik integratif melalui model webbed lebih baik daripada siswa yang belajar dengan direct instruction.

Hal yang sama juga terjadi pada peningkatan kemampuan koneksi matematis siswa ditinjau dari level kemampuan siswa tinggi dan rendah. Berdasarkan analisis data yang telah dilaksanakan menunjukan bahwa terdapat perbedaan peningkatan kemampuan koneksi matematis siswa yang belajar dengan pendekatan tematik integratif melalui model webbed dan siswa yang belajar dengan direct instruction ditinjau dari level kemampuan siswa tinggi dan rendah.

Tidak jauh berbeda dengan peningkatan kemampuan koneksi matematis siswa ditinjau dari level kemampuan siswa tinggi dan rendah, kemampuan koneksi berdasarkan tiap level kemamapuan siswa juga mengalami peningkatan. Dari hasil perhitungan melalui uji anova dua jalur diketahui bahwa terdapat pengaruh interaksi level kemampuan siswa dan model pembelajaran terhadap peningkatan kemampuan koneksi matematis siswa.

Berdasarkan hasil analisis data kemampuan koneksi matematis siswa kelompok tinggi yang belajar dengan pendekatan tematik integratif melalui model webbed lebih baik daripada siswa kelompok tinggi yang belajar melalui direct instruction. Sama hal nya dengan peningkatan kemampuan koneksi matematis pada level KAM siswa rendah, berdasarkan hasil penelitian juga menunjukan bahwa kemampuan koneksi matematis siswa kelompok rendah yang belajar dengan pendekatan tematik integratif melalui model webbed lebih baik daripada siswa kelompok rendah yang belajar melalui direct instruction.

Hal ini dikarenakan pada pembelajaran tematik integratif melalui model webbed dalam proses pembelajarannya melibatkan sebuah tema yang berkaitan dengan beberapa mata pelajaran yang dapat mengembangkan dan bahkan meningkatkan kemampuan koneksi matematis. Dengan adanya sebuah tema yang dijadikan sebagai jembatan dalam mempelajari beberapa mata pelajaran yang saling berkaitan siswa dapat memandang suatu pembelajaran sebagai sesuatu yang bersifat holistik (utuh). Dengan memanadang pembelajaran sebagai sesuatu yang bersifat utuh, maka siswa akan dapat memahami materimateri yang dipelajarinya dengan seutuhnya.

Selain itu dalam langkah-langkah pembelajaran tematik integratif melalui model webbed terdapat fase mengamati, menanya, mengumpulkan informasi, eksperimen, mengasosiasi/menalar dan mengkomunikasikan. Dalam fase mengamati siswa diberi kesempatan untuk melakukan pengamatan terhadap objek nyata (konkret) di dalam sebuah pembelajaran. Hal ini sangant penting karena dengan mengamati benda secara konkret akan 
membantu siswa dalam membangun pengetahuannya melalui sebuah pengalaman secara nyata (konkret).

\section{KESIMPULAN}

Berdasarkan hasil analisis data dan pengujian hipotesis peneltian yang telah dikemukakan pada bab sebelumnya, dapat diambil beberapa kesimpulan sebagai berikut :

1. Kemampuan koneksi matematis siswa yang belajar dengan pendekatan tematik integratif melalui model webbed lebih baik daripada siswa yang belajar dengan direct instruction.

2. Peningkatan kemampuan koneksi matematis siswa yang belajar dengan pendekatan tematik integratif melalui model webbed lebih baik daripada siswa yang belajar dengan direct instruction ditinjau dari level kemampuan siswa tinggi dan rendah.

3. Terdapat pengaruh interaksi level kemampuan siswa dan model pembelajaran terhadap peningkatan kemampuan koneksi matematis siswa.

4. Kemampuan koneksi matematis siswa kelompok tinggi yang belajar dengan pendekatan tematik integratif melalui model webbed lebih baik daripada siswa kelompok tinggi yang belajar melalui direct instruction.

5. Kemampuan koneksi matematis siswa kelompok rendah yang belajar dengan pendekatan tematik integratif melalui model webbed lebih baik daripada siswa kelompok rendah yang belajar melalui direct instruction.

\section{REKOMENDASI}

Berdasarkan kesimpulan di atas, maka peneliti dapat memberikan saran-saran sebagai berikut :

1. Berdasarkan hasil penelitian, menunjukkan bahwa pembelajaran matematika dengan pendekatan tematik integratif melalui model webbed dan melalui direct instruction dapat meningkatkan kemampuan koneksi matematis siswa SD. Oleh karena itu, disarankan pembelajaran dengan pendekatan tematik integratif melalui model webbed dan direct instruction dapat menjadi salah satu alternatif yang dapat digunakan guru matematika dalam menyajikan materi matematika.

2. Untuk peneliti selanjutnya disarankan untuk untuk melakukan penelitian studi komparatif tentang kemampuan-kemampuan matematis yang lain, misalnya tentang kemampuan pemecahan masalah, kemampuan penalaran, kemampuan komunikasi, 
kemampuan pemahaman, ataupun kemampuan representasi matematis dengan pendekatan tematik integratif melalui model webbed dan direct instruction.

3. Tema yang diangkat pada pembelajaran dengan pendekatan tematik integratif melalui model webbed dalam penelitian ini adalah tema daerah tempat tinggalku dan materi yang dibahas dalam penelitian ini adalah bangun ruang (balok, kubus, kerucut, tabung, dan bola), jaring-jaring kubus dan balok, mengenal bangun datar simetris, dan pencerminan bangun datar, maka dari itu untuk peneliti selanjutnya disarankan untuk melakukan penelitian studi komparatif tentang pendekatan tematik integratif melalui model webbed dan direct instruction terhadap tema dan topik lain yang berbeda dengan yang sudah dilakukan oleh peneliti.untuk peneliti selanjutnya bahwa metode Problem Based Learning $(P B L)$ ini dapat di terapkan pada materi yang lainnya disesuaikan kemampuan matematis apa yang ingin di ukur.

\section{REFERENSI}

Akdon. (2005). Aplikasi Statistika Dan Metode Penelitian Untuk Sdministrasi dan Manajemen. Bandung : Dewa ruchi

Creswell, J. W. (2012). Research Design: pendekatan kualitatif, kuantitatif, dan mixed. Yogyakarta: Pustaka Pelajar

Dahar, R.W. (2006). Teori-Teori Belajar dan Pembelajaran. Jakarta: Erlangga

Herman. (2007). Model Pembelajaran Matematika di Sekolah Dasar. Bandung: PT. Remaja Rosdakarya

Hudojo, H. (2005). Pengembangan kurikulum dan Pembelajaran Matematika. Malang: Universitas Negeri Malang

Kurniawan, D. (2011). Pembelajaran Terpadu Teori, Praktik dan Penilaian. Bandung: CV. Pustaka Cendikia Utama

Kusumah, Y.S. (2008). Konsep pengembangan, dan implementasi komputer-based learning dan peningkatan kemampuan high-order mathematical thinking. Disampaikan dalam pidato pengkuhan sebagai guru besar pada FPMIFA UPI Bandung.

Kutz, R.E. (1991). Anotated Instructor's Edition, Teaching Elementary Mathematics. Boston : Allyn and Bacon.

National Concuil of Teacher of Mathematics (NCTM). (1989). Curriculum And Evaluluations Standards For School Mathematics. Reston, VA : Authur

Ontario Ministry Education. (2005). Capacity Building Series, Coommunication in the mathematics Classroom Special Edition \#13. Ontario : Reach Every Student.

Pamungkas. S. A. (2013). Pembelajaran Eksplorasi untuk Mengembangkan Kemampuan Berpikir Logis dan Self Concept Matematis Siswa Sekolah Menengah Pertama. Tesis pada SPs UPI Bandung. Tidak Dipublikasikan. 
Ruseffendi, H. E. T. (2005). Dasar-Dasar Penelitian Pendidikan dan Bidang Non Esakta Lainnya. Bandung: Tarsito.

Sanjaya, W. (2006). Strategi pembelajaran berorientasi standar proses pendidikan. Jakarta : Kencana Prenada Media

Santoso, S. (2001). SPSS versi 10. Jakarta : Gramedia

Sa'ud, U.S. (2006). Pembelajaran Terpadu. Bahan belajar mandiri pada program peningkatan kualifikasi guru SD/MI di Bandung.

Slavin, R. E. (2011). Psikologi Pendidikan : teori dan praktik. Jakarta: Indeks.

Suherman, dkk. (2003). Strategi Pembelajaran Matematika Kontemporer. Bandung : JICA UPI Bandung.

Sumarmo, U. (2013). Kumpulan Makalah: berpikir dan disposisi matematik serta pembelajarannya. Bandung: Universitas Pendidikan Indonesia.

Suryadi, D \& Herman, T. (2008). Eksplorasi Matematika Pembelajaran Pemecahan Masalah. Karya Bandung: Duta Wahana

Susetyo, B. (2010). Statistika untuk Analisis Data Penelitian. Bandung: Refika Aditama.

The National Council of Teachers of Mathematics (NCTM). (2000). Principles and Standards for School Mathematics. Reston,VA: NCTM.

Trianto. (2010). Pengembangan Model Pembelajaran Tematik. Jakarta : Prestasi Pustaka

Wahyudin.(2012). Filsafat dan Model-Model Pembelajaran Matematika. Bandung: Penerbit Mandiri.

Yaniawati, P. (2001). Pembelajaran Dengan Pendekatan Open-Ended Dalam Upaya Meningkatkan Kemampuan Koneksi Matematika Siswa. Tesis Magister Pada Sekolah Pascasarjana UPI Bandung: tidak diterbitkan. 